\title{
Catching-Up and Falling Behind: Knowledge Spillover from American to German Machine Toolmakers
}

\author{
RALF RICHTER AND JOCHEN STREB
}

\begin{abstract}
Today, German machine toolmakers accuse their Chinese competitors of violating patent rights and imitating German technology. A century ago, German machine toolmakers used the same methods to imitate American technology. To understand the dynamics of this catching-up process, we use patent statistics to analyze firms' activities between 1877 and 1932. We show that German firms deployed imitating strategies in the late nineteenth century and the 1920 s to catch-up to their American competitors. The German administration supported this strategy by stipulating a patent law that discriminated against foreign patent holders and by delaying the granting of patents to foreign applicants.
\end{abstract}

\section{Tn March 2008 the Association of German Machine Builders (Verband Deutscher Maschinen- und Anlagenbauer) complained of the notorious Chinese product piracy: "More than half of German machine builders discover illegal replicas at exhibitions. Three-quarters of these replicas come from China. Unfortunately, China's entry into the WTO in 2001 has not improved the legal protection of intellectual property rights of foreign firms. ${ }^{1}$ The resulting loss to German mechanical engineering is about seven billions euros per year (or about 4 percent of total sales)." ${ }^{2}$ The Association of German Machine Builders did not mention that, a century ago, many of its members relied on counterfeiting strategies to}

The Journal of Economic History, Vol. 71, No. 4 (December 2011). (C) The Economic History Association. All rights reserved. doi: 10.1017/S0022050711002221.

Ralf Richter is Research Assistant, Hans Böckler Foundation, Hans-Böckler-Straße 39, 40476 Düsseldorf, Germany. E-mail: Ralf-Richter@boeckler.de. Jochen Streb is Professor, Department of Economics and Social Sciences, University of Hohenheim (570a), 70593 Stuttgart, Germany. E-mail: j-streb@uni-hohenheim.de.

We are very grateful for many helpful comments from Harald Degner, Timothy W. Guinnane, Zorina Khan, Alessandro Nuvolari, Jean-Laurent Rosenthal, José Patricio Sáiz, Ross Thomson, the organizers and participants of the workshop, "Towards a Global History of Production I: Machine Tools and the International Transfer of Industrial Technology," at Cambridge in March 2009, the session, "Innovation Systems and Economic Performance: Past Leaders, Catch-Up Countries and New Latecomers (20th-21st centuries)," at the XVth World Economic History Congress at Utrecht in August 2009, the Economic History Association Annual Meeting at Evanston in September 2010, and three anonymous referees.

${ }^{1}$ Argumentationshilfe aus dem VDMA zum Stichwort Produktpiraterie, Press release VDMA, March 2008.

${ }^{2}$ Produkt- und Markenpiraterie in der Investitionsgüterindustrie 2008, Press release VDMA, April 2008. 
catch up to their British and American competitors. As early as 1897, the periodical American Machinist observed: "In going through the shops of a prominent German machine-tool builder who has been in the United States and got a good many ideas there from, as well bought a good line of the best standard machines from which to copy or vary, in the production of its own line, I notice that every solitary American machine, whether from Providence, New Haven, or Cincinnati, had had the name chipped off and the place painted over." ${ }^{3}$ Thirty years later, in 1927, the French periodical La Machine Moderne reported: "Information coming from Germany indicates that a number of American machine-tools are being copied now by German manufacturers, some of which are made without the slightest alteration. Most of these machines are actually sold as originals, the name of the American constructor of the original machine being mentioned in the advertising notices, and often even appearing stamped on the machine, with the indication 'type' or 'model." We can cite a case where a German firm copied a machine designed and built by a well-known American manufacturer, and sold in the United States." 4

We claim in this article that imitating and even counterfeiting advanced foreign technology and products are typical strategies of firms located in an economically backward country. ${ }^{5}$ These activities are formally legal when the imitating firms sell only in those markets where the intellectual property rights of the original inventor are not protectedlike in Germany before 1877 . These activities are clearly illegal when the imitating firms peddle their replicas in places where the original inventor has valid intellectual property rights - like in the case reported by $L a$ Machine Moderne.

Ineffective intellectual property rights are a necessary but not sufficient precondition for the occurrence of methodical imitating activities. At least two other preconditions have to be satisfied to motivate a firm from a backward country to engage systematically in imitating superior foreign technology. ${ }^{6}$ First, the potential imitator has to have available the stock and structure of human capital that is requisite to reproduce the foreign

\footnotetext{
3 "German Machine Copying," American Machinist (February 1897), 116. According to Kiesewetter, the lawyers of McCormick, an American manufacturer of agricultural machinery, accused the German imitators of being the most infamous pirates in nineteenth-century Europe. See Kiesewetter, "Beasts," p. 170.

${ }^{4}$ U.S. National Archives and Records Administration [hereafter NARA], W. H. Rastall, 2 May 1927, RG 151, 413 (Box 1806).

${ }^{5}$ For theoretical models explaining historical catching-up processes by learning by imitating, see, for example, Goodfriend and McDermott, "Industrial Development"; and Kelly, "Technological Progress."

${ }^{6}$ Other factors such as an incorruptible administration, openess to competition, or financial institutions capable of mobilizing capital for industrial firms seem to be also needed for catching-up successfully by imitation strategies. See Abramovitz, "Catching-Up"; and Buchheim, "Development."
} 
innovation. Philippe Aghion supposes that during the imitation phase firms rely primarily on workers with secondary education while for independent innovation workers with tertiary education are needed. Second, to gain significant market shares, the potential imitator has to be able to undercut the innovator's price due to lower production cost. In 1882, for example, the German machine tool builders offered their replicas of American machine tools in London at a price that was between 25 and 40 percent lower than the one of the American innovators. $^{8}$

In his seminal work, David Landes claims that "this readiness and even eagerness to learn from others [. . .]-industrial espionage is a theme running all through modern European history-was testimony to an already thriving indigenous technology; good innovators make good imitators." 9 In our opinion, even more important is the reverse causality: good imitators become good innovators. To elaborate this argument, we subdivide the catching-up process into the two periods, imitation and innovation. During the imitation period, the backward country's domestic firms oppose any strict patent law and use various channels such as reverse engineering, visiting international exhibitions and foreign firms, analyzing patent specifications, or hiring foreign craftsmen and engineers to imitate their superior foreign competitors. ${ }^{10}$ Learning by imitating might enable these firms to develop innovations on their own. If they judge their newly acquired capability to innovate more profitable than their traditional imitating strategy, a period of innovation will follow the period of imitation. As this process of innovating gains momentum, domestic firms might favor tightening domestic patent law. They might even agree to end any discrimination against foreign firms, because that is necessary for having their own intellectual property rights enforced abroad.

In practice, the imitation and innovation phases often overlap. After domestic innovation gets underway, illegal imitation of foreign technology might become less common, and, second, increasing imitation activities between domestic firms might increase the diffusion of knowledge within the backward country. A larger knowledge base

\footnotetext{
${ }^{7}$ Aghion, "Higher Education." For the successful coevolution of human capital formation and innovative firms in the German chemical industry, see Grupp, Dominguez-Lacasa, and Friedrich-Nishio, Das deutsche Innovationssystem; and Murmann, Knowledge.

8 "Copying Machine Tools Abroad," American Machinist (April 1882), 8.

${ }^{9}$ Landes, Unbound Prometheus, p. 28.

${ }^{10}$ To avoid misunderstandings, we want to stress that technological transfer is seldom a oneway street. During the catching-up process, firms in the technologically leading country might also learn from the activities of their foreign imitators. For this "reverse flow," see Jeremy, International Technology Transfer.
} 
would provide more and more domestic firms' ability to develop innovations. In turn, a higher rate of innovation increases both price and Schumpeterian competition among domestic firms, creating even greater incentives to innovate. In the best of circumstances, domestic firms might even take over the global technological leadership and thereby-like the German machine toolmakers-change from ruthless imitators to campaigners for the worldwide enforcement of intellectual property rights.

Japanese firms in various sectors went through this catching-up process successfully in the second half of the twentieth century; Chinese firms seem to be doing so today. We will concentrate on the development of the German machine tool industry between 1877 and 1932; it was one of the examples that inspired the efforts of other successful cases. In section 2, we present a case study to illustrate how this catching-up process worked at the firm level. The rest of the article focuses on patenting by German and American machine toolmakers. We analyze the chronology of the catching-up process, the German patent practice discriminating against foreign applicants, and the American firms' responses.

\section{REINECKER'S PATH FROM IMITATION TO INNOVATION}

To illustrate the chronological sequence and the channels of knowledge transfer from American to German machine toolmakers, we look more closely at the development of $J$.E. Reinecker, a firm founded in 1859 in Chemnitz. ${ }^{11}$ This firm began by making parts (rather than whole machines). Its imitation phase began at the World's Fair in Vienna in 1873 where the firm's founder bought a Brown \& Sharpe Mfg. Company grinding machine. The firm then copied this American product to start up its own machine tool production. ${ }^{12}$ Interestingly enough, an American correspondent at the World's Fair in Vienna had anticipated that such imitation strategy would arise: "A considerable number of American tools were sold to continental makers, and are probably to be copied at once for the European markets." ${ }^{\prime 13} J$. E. Reinecker, indeed, learned from this initial experience and relied on imported American machine tools to expand its product range over the following decades. By 1915 the firm had bought more than 100 machine tools from 21 different American manufacturers. Generally, J. E.

\footnotetext{
${ }^{11}$ For more case studies supporting the basic claims of this article, see Richter, "Werkzeugmaschinenbau."

${ }^{12}$ Reinecker, p. 10.

${ }^{13}$ Thurston, Report, p. 202.
} 
Reinecker acquired only one, rarely two machine tools of the same type. ${ }^{14}$ In Chemnitz, the process of reverse engineering began by first completely disassembling the imported machine tool. Then, every component was analyzed and recorded with the help of engineering drawings. Then $J$. E. Reinecker embarked on process of producing replica parts until it could manufacture fully functional copies of the original American machine tool.

$J$. E. Reinecker did not rely on solely trade fairs and world exhibitions to learn about new machines. ${ }^{15}$ International trade journals and American patent specifications were also important sources of knowledge about foreign innovations. ${ }^{16}$ As it intensified its imitation efforts, personal, often tacit, knowledge became more and more important. That is why, in 1882, the founder's son traveled to the United States. He visited many American plants and even worked there temporarily. ${ }^{17}$ The publication commemorating the 50th anniversary of J. E. Reinecker explicitly stressed that the experience the founder's son gained during his stay abroad had played a major role in its technological progress. ${ }^{18}$ In addition, in $1897 \mathrm{~J}$. E. Reinecker hired an American expert who had presented the innovations of a Philadelphia firm at the Chicago World Exhibition in $1893 .{ }^{19}$ Over time, the firm came to rely on information about innovative machine tools distributed by international resellers among the different (German and foreign) firms they represented. ${ }^{20}$ The world's largest reseller of machine tools, Schuchardt \& Schütte in Berlin, for example, informed $J$. E. Reinecker regularly about the latest technological development in the United States. ${ }^{21}$

\footnotetext{
${ }^{14}$ Staatsarchiv Chemnitz [hereafter StA Chemnitz], Schätzungsprotokolle über Betriebsgegenstände, 1915, 31007/131.

${ }^{15}$ World exhibitions were the places were major innovations were presented to an international audience. See Moser, "Patent Laws."

${ }^{16}$ Already in 1897, another German firm, the machine toolmaker Schubert \& Salzer, employed a translator to scrutinize the sixty international trade journals the firm had subscribed to. See Miller, Machinery Abroad, p. 72.

${ }^{17}$ Unfortunately, our source does not reveal the name of the American firms where the founder's son worked. However, we have this kind of information, for example, for the Werkzeugmaschinenfabrik Gebr. Heinemann. In this case, the founder's son worked successively at Lodge \& Shipley in Cincinnati, Bardons \& Oliver in Cleveland, and Pratt \& Whitney in Hartford. Gebr. Heinemann, pp. 1-4.

${ }^{18}$ Reinecker, p. 15.

${ }^{19}$ Miller, Machinery Abroad, p. 76.

${ }^{20}$ In contrast to other industries in which sales agencies acted as "information brokers," machine tool dealers did not charge their clients for new information about the innovations of their competitors. Instead, they used this kind of knowledge transfer as a mean to improve the competitiveness of their clients' products. For the role of international resellers as "information brokers," see Streb, "Möglichkeiten."

${ }^{21}$ Reinecker, pp. 10-15; and Miller, Machinery Abroad, p. 76.
} 
Due to this continuous and multifaceted transatlantic knowledge transfer and the subsequent learning by imitating, J. E. Reinecker changed from a pure imitator of American technology to an independent innovator. In $1878 \mathrm{~J}$. E. Reinecker patented its first major innovation that was a machine tool which could be used to grind spiral drills and was inspired by the various grinding machines the firm had acquired from Brown \& Sharpe since $1873 .^{22}$ By $1900 \mathrm{~J}$. E. Reinecker had already applied for 37 patents in Germany, five of these were also filed in the United States. Even the American trade press acknowledged the outstanding innovativeness of this German firm. Fred Miller, editor of the American Machinist, described the positive impression he had gained during a visit at the $J$. E. Reinecker's production facility: "There is in the products of this shop much more original work than is to be found in the work of a large proportion of our own shops, and I am convinced that the net result of the fact that such a concern as this chooses to adopt the underlying principles of our American tool designs and to follow them rather than British ideas is a distinct gain for the American tool builder, even in German trade itself.,"23

J. E. Reinecker's successful transition from imitator to innovator was short-lived. Indeed World War I dealt a nearly mortal blow to its attempt to join the elite of international toolmakers. The Allied trade embargo of Germany obviously isolated the firm from both international competition and from information about new foreign machine tools. During the war, German machine toolmakers had to stop their producing high-quality machine tools and instead made large numbers of low-quality machines for ammunition and weapons production. There was no point in investing in new R\&D projects for cutting-edge machines. ${ }^{24}$ The war also hurt the firm's human capital because many experienced machine toolmakers were drafted and replaced by unskilled workers. Not surprisingly, J. E. Reinecker switched focus and used its new unskilled workers and most of its production capacity to manufacture ammunition instead of complex machinery. Overall, J. E. Reinecker's prewar innovative momentum was broken and the firm fell far behind its American competitors. ${ }^{25} J . E$.

\footnotetext{
${ }^{22}$ See Deutsches Patent- und Markenamt, Patent No. 34,540.

${ }^{23}$ Miller, "German Tool Shop," American Machinist (November 1898), 818.

${ }^{24}$ Bundesarchiv Berlin-Lichterfelde [hereafter BArch], Stenographischer Bericht über die Besprechung in den Geschäftsräumen des Vereins Deutscher Werkzeugmaschinenfabriken, 5 September 1916, R 8099/259, pp. 26-32.

${ }^{25}$ The technological development of the American machine tool industry was apparently not as negatively affected by the First World War. Quite the contrary, the steady demand of both the automobile industry and the armament industry for more and more efficient machine tools fostered American machine tools innovations also during war times. See, for example,
} 
Reinecker's technological stagnation is highlighted by the fact that it was awarded only three patents between the end of the First World War and 1927, which comes to only about 11 percent of the number of patents the firm had received between 1890 and 1913.

After the war, it was not a surprise that $J$. E. Reinecker reverted to its ancient imitation strategy. In 1926 the Department of Commerce in Washington and the American Embassy in Berlin singled out the aggressive imitation strategies of the former innovator $J$. E. Reinecker among German product pirates who should be taken to the German patent court. Their reports highlighted that the firm offered an illegal replica of the "three spindle gear rougher" for only two-thirds of the price demanded by its American inventor Gould \& Eberhardt. Another case involves the American firm Lees-Bradner Company. By 1925 it had sold 75 units of its "spur gear grinders" in Germany for 2,200 Reichsmarks per unit. In 1925, however, J. E. Reinecker offered a replica at a price of only 1,200 Reichsmarks, and stole the German, British, and French markets from the Lees-Bradner Company. ${ }^{26} J$. E. Reinecker did not to resume significant innovation until the late 1920s and its first new U. S. patent application was filed in $1932 .{ }^{27}$

$J$. E. Reinecker's business history suggests that the catching-up process occurred in two consecutive steps. The pre-First World War catching-up process is characterized by an imitation phase until the 1890 s and an innovation phase until the outbreak of the war. After a severe technological setback during the First World War the catchingup process resumed. Again, it had to rely on imitation strategies in the 1920s but finally regained its ability to innovate in the early 1930s. This second catching-up process was faster than the first one because the technological gap was smaller and imitation channels of the 1920s were more intense than in the mid-nineteenth century. In the following sections, we shall show that this pattern was general among German machine toolmakers using patent data.

\section{THE PATENT DATA}

Our analysis of the patenting activities of the American and German machine tool industries is based on different samples of individual

Cincinnati Historical Society Library [hereafter CHSL], Milacron, Series Frederick V. Geier, Box 53: Amortization of Machine Tools, May 1930.

${ }^{26}$ NARA, RG 151, 420 (Box 1950): D. P. Miller to the Director Bureau of Foreign and Domestic Commerce, 8 November 1926.

${ }^{27}$ United States Patent and Trademark Office [hereafter USPTO], Patent No. 1,885,628, Arbor support for gear cutting machines. 
machine tool patents, with each single record including information about the year when the patent was granted (or applied for), as well as the name and location of the firm holding the respective patent. To identify the machine tool patents in the total patent population, we use the fact that the German patent office, starting with the introduction of the German patent law in 1877 , assigned every patent to a particular technological class. ${ }^{28}$ Patents covering the technology of the machine tool industry can be found in the patent classes 47 (machine parts), 49 (mechanical metal working), and 67 (grinding and polishing). ${ }^{29}$ As these patent classes also contain innovations that do not belong to the machine tool technology, we identified the relevant patents with the help of the description of the innovation. Every patent that dealt with machining or chipping metal was selected.

We analyze three different types of patent statistics: Patents applied for are a measure for inventions which were appraised to be new and potentially profitable by the applying firms. Patents granted, in contrast, are a measure for inventions which were judged to be new by the patent office. Valuable (or long-lived) patents cover those innovations which became in fact profitable. ${ }^{30}$ It is important to note that these three types of patents do not necessarily display a parallel development over time. Figure 1 shows, for example, that the machine toolmakers of the industrial district Chemnitz had a rather constant annual number of valuable patents while their number of patents granted was especially high in the 1890s and the 1920s. It would therefore be wrong to infer from the rising number of patents granted a similar boom of valuable patents and therefore of profitable innovativeness. $^{31}$

In this article, we match the Baten-Streb patent database (about 66.700 valuable patents for the period 1877-1932) with Richter's patent data about the patenting activities of American and German machine toolmakers for four different groups of patent holders which vary in the depth of patent information available: ${ }^{32}$ (1) A first data set contains 425

\footnotetext{
${ }^{28}$ Seckelmann, Industrialisierung, pp. 86-106.

29 "Machinery patents" can also be found in less obvious classes like 45 (agriculture $\rightarrow$ agricultural machinery) or 86 (weaving $\rightarrow$ textile machines) to name just a few. Innovative machine tools, however, were assigned to the three classes 47,49 , and 67 .

${ }^{30}$ In Germany, a patentee had to pay at the beginning of each year an increasing renewal fee in order to keep his patent in force. Under this assumption, a long life span of a historical patent indicates its comparatively high private economic value. We selected all patents that survived at least ten years. For details, see Streb, Baten, and Yin, "Knowledge Spillover."

${ }^{31}$ The region Chemnitz did not participate in the increase in valuable patents of the German machine tool industry in the late 1920s depicted in Figure 2 because of decreasing relative innovativeness. See Figure 7.

${ }^{32}$ In contrast to the American patent law, German patents were not granted to the inventor but
} 


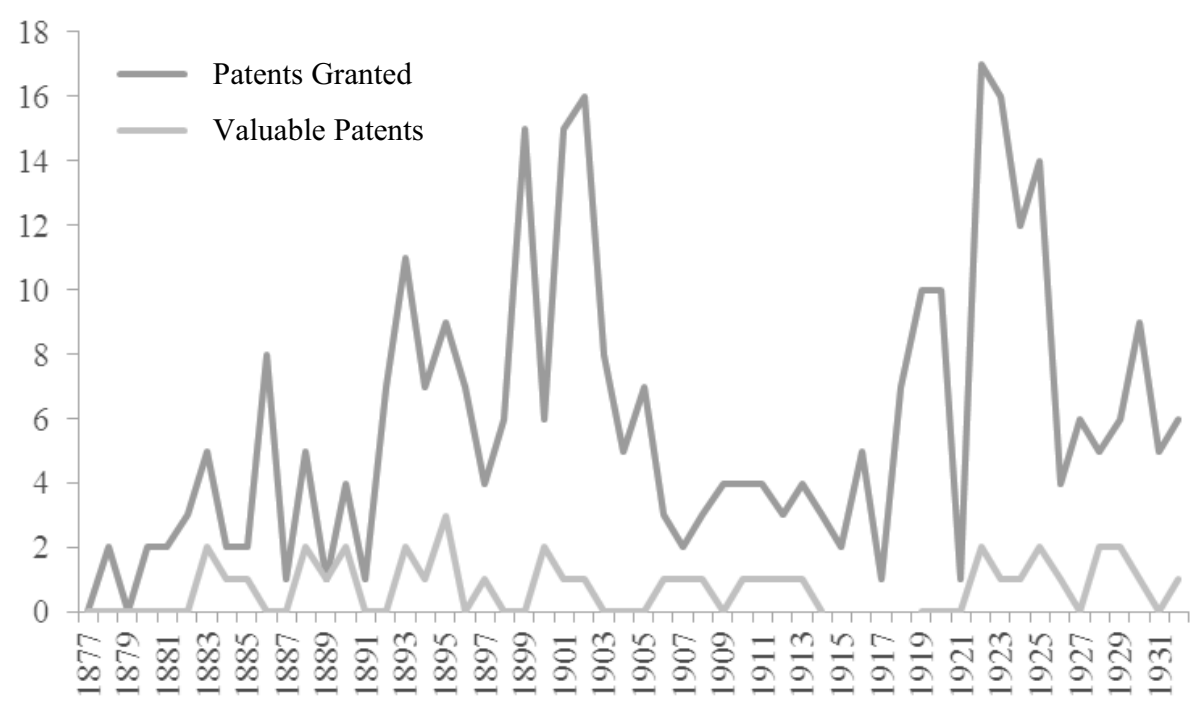

FIGURE 1

PATENTS GRANTED AND VALUABLE PATENTS OF THE MACHINE TOOLMAKERS IN CHEMNITZ

Sources: Baten-Streb patent database and Richter's patent data (both available upon request).

valuable patents granted to one of 479 firms that were a member of the association of German machine toolmakers between 1891 and 1932 or were identified as machine toolmakers in trade journals published between 1870 and 1932; (2) A second data set involves those firms in the industrial district of Chemnitz (the birthplace of the German machine tool industry). For these firms, we have not just their 40 valuable patents, but all 352 patents they received; (3) A third data set includes information on their 688 patents granted in Germany including the application date and 62 valuable German patents granted to one of 408 American firms that were either member of the Association for Manufacturing Technology (or its predecessor, the National Machine Tool Builders Association); or were identified as machine toolmakers in trade journals; (4) A fourth data set involves American machine toolmakers in the Cincinnati industrial district of Cincinnati which was, along with New England and Philadelphia, one of the most important focal points of the American machine tool industry. For those firms, we have their 48 German patents including two valuable ones and their 1,165 American patents.

to the person or corporate entity who or which filed the respective patent first. Especially, German firms filed patents for all inventions that were developed by their employees. As a result, the German market for patents was comparatively small. See Burhop, "Transfer." 


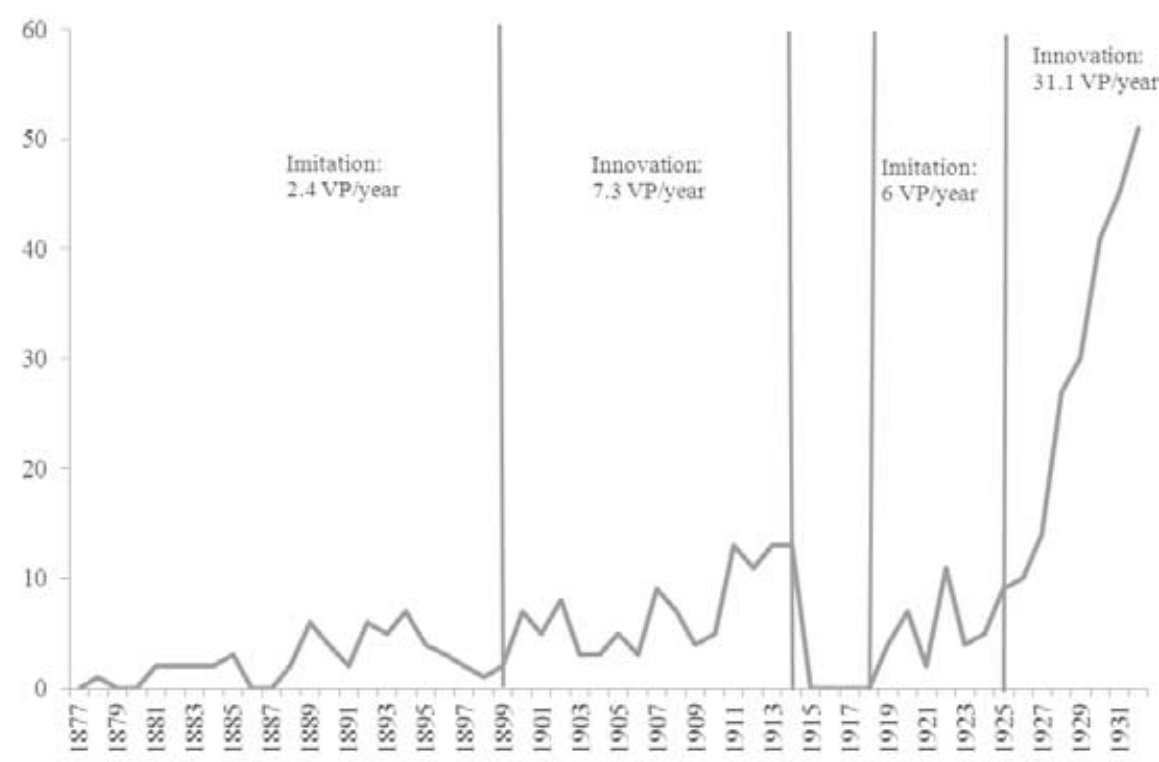

FIGURE 2

VALUABLE PATENTS (VP) OF GERMAN MACHINE TOOLMAKERS

Sources: Baten-Streb patent database and Richter's patent data (both available upon request).

We use these four patent data sets to analyze the details of German machine toolmakers' catching-up process in the following section.

\section{GERMAN MACHINE TOOLMAKERS' CATCHING-UP}

Figure 2 shows that the average annual number of valuable patents received by German machine toolmakers matches the qualitative evidence about the timing of the repeated catching-up process: The first imitation period starts with the Paris World Exhibition in 1867 and ends about 1899 with an average of 2.4 valuable patents per year. ${ }^{33}$ It is followed by the first innovation period (1900 to the outbreak of the First World War) when the number of average valuable patents rises to 7.3 per year. Patenting rates collapse during World War I. A second imitation period runs 1919 to 1925 with 6 valuable patents per year,

\footnotetext{
${ }^{33}$ Our qualitative evidence suggests that the first imitation period already started in the late 1860s. Since the German patent law was not introduced until 1877, we are not able to analyze the first decade of this imitation period with the help of patent data. Interestingly enough, however, it was apparently the growing imitating activities of German firms in the early 1870s which considerably increased the international political pressure on Germany to introduce a patent law. See Seckelmann, Industrialisierung, p. 156.
} 
followed by a second innovation period (1926 to 1932, which is the last year covered by our data) with 31.1 valuable patents per year.

The fact that, during the first imitation period, German machine toolmakers applied for only a few patents that turned out to be worth prolonging for at least ten years suggests that, in the late nineteenth century, the German firms neglected their own R\&D projects and relied primarily on imitating foreign products. As the example of $J$. E. Reinecker demonstrates, ${ }^{34}$ learning by imitating contributed in the longer run to the creation of the R\&D capabilities that were needed to develop successful innovations on their own account. The average number of valuable patents per year awarded to the German machine tool industry tripled in the first innovation period in comparison to the preceding first imitation period. However, we should not draw a sharp line between these two periods. The transition from imitating to innovating was gradual in the late nineteenth century.

The absence of valuable German machine tool patents between 1915 and 1918 in Figure 2 does not indicate the total breakdown of innovation in the sector, but is due to the fact that the German patent office did not publish the name of any patent holder during the First World War. Our case study of the machine toolmaker J. E. Reinecker suggests, however, that the German machine toolmakers could not maintain their technological leadership during the war. ${ }^{35}$ Consequently, after the war had ended, many German machine toolmakers went back to their well-known imitation strategies which they had already brought to perfection in the nineteenth century. They concentrated now especially on imitating the new centerless grinding machines which had been developed for the advanced American automobile industry. Any scruples which the German firms might have had against violating of intellectual property rights must have been overcome by the U.S. Office of Alien Property's wartime confiscation of their U.S. patents. ${ }^{36}$ As late as 1926, the American commercial attaché in Berlin declared: "The practice of copying American machinery has therefore extended much more widely since the war than it was even before. ${ }^{37}$ In any case, their past experience with imitation must have helped German machine

\footnotetext{
${ }^{34}$ For other case studies, see Richter, "Werkzeugmaschinenbau."

${ }^{35}$ This argument is not only supported by our case studies but also by the patent statistics. Even though the average annual number of valuable patents is in the second imitation period (1919-1925) only slightly lower than in the first innovation period (1900-1914), a closer look at Figure 2 reveals that, in the postwar years, the German machine toolmakers did not reach the high number of valuable patents per year they gained from 1911 to 1914.

${ }^{36}$ The war-induced American-German patent conflict was settled with the Nolan Act of March 3, 1921.

${ }^{37}$ NARA, RG 151, 420 (Box 1950): D. P. Miller to Director Bureau of Foreign and Domestic Commerce, 8 November 1926.
} 


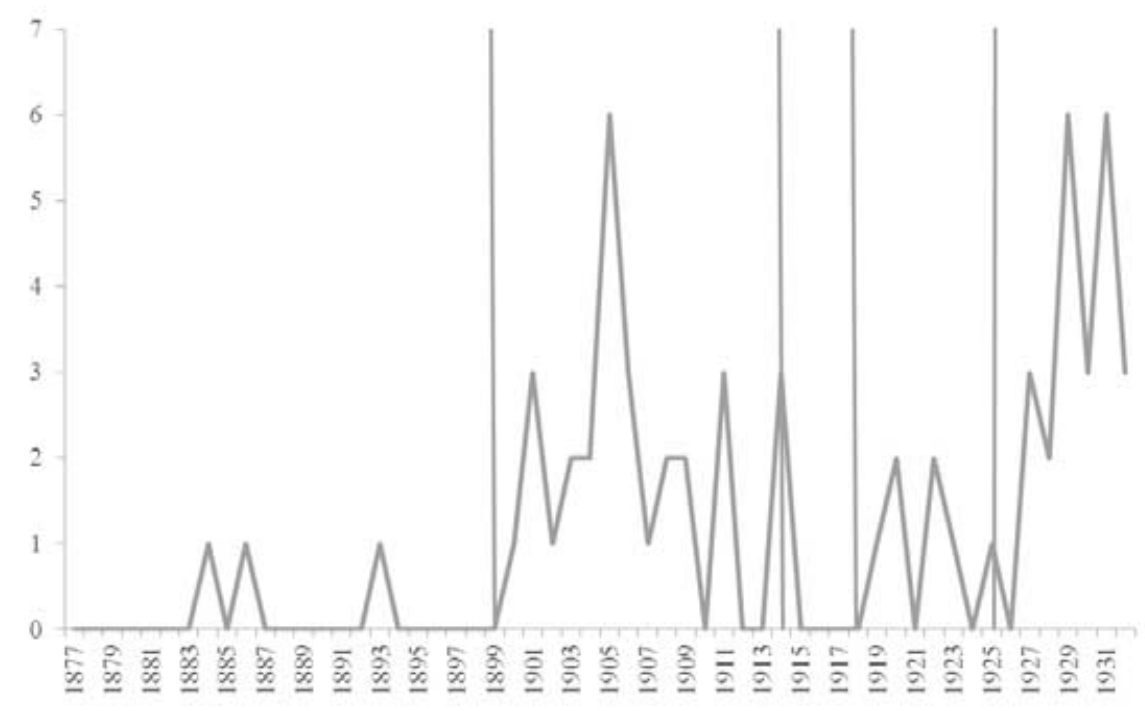

FIGURE 3

VALUABLE PATENTS OF AMERICAN MACHINE TOOLMAKERS IN GERMANY

Sources: Baten-Streb patent database and Richter's patent data (both available upon request).

toolmakers to resume production at a high rate and to catch-up again in just a half decade. In 1926 the German machine tool industry started to pass through its second innovation period with an unprecedented average number of 31.1 valuable patents per year.

How did the American producers react to German firms' copies of their machine tools in the late nineteenth and early twentieth centuries? We already know about that there were complaints about German activities both during the first and the second imitation period. It is reasonable to assume that the American innovators fought not just with words, but also tried to protect their intellectual property rights by applying for patents in Germany. ${ }^{38}$ Figure 3 shows that American firms did not garner high number of either standard or valuable German patents during the two imitation periods. In fact, their patenting was high in the two innovation periods. ${ }^{39}$ How can this empirical observation be explained?

\footnotetext{
${ }^{38}$ As is true today, the distribution of foreign patents across countries was highly skewed. The United States dominated foreign patenting activities in Germany with a share in all longlived foreign patents of 29 percent before and 35 percent after the First World War-and were, therefore, Germany's major source for new technological knowledge. See Degner and Streb, "Foreign Patenting."

${ }^{39}$ The American machine tool industry's share in all valuable American patents in Germany is
} 
There are two necessary conditions for a firm to seek a patent in a foreign country: An innovator will only apply for a patent in a particular foreign market if he expects to sell his products there at a sales volume that justifies the costs that come along with the patenting activities abroad. It must also be the case that the application procedure was not too biased against foreigners. As we shall see, both conditions play an important role in explaining the chronology of American patenting in Germany.

The surprising parallels in foreign (American) and domestic patenting activities suggest that patent propensity might be positively related to the growth of German industries that made use of machine tools. Thus as long as these industries remained small, American firms had little incentive to patent in Germany. The rise in valuable patents up to 1914 might mirror the growth of domestic and foreign machine tool sales in Germany while the decline in patents after the First World War might reflect the depressed conditions of the interwar period. To evaluate this hypothesis, we compare American patenting activities in Germany with German machine tool imports. ${ }^{40}$ We therefore use two time series: first, the nominal value of imported machines of every kind between 1880 and $1913,{ }^{41}$ and, second, the nominal value of imported machine tools between 1908 and $1932 .{ }^{42}$ The correlation coefficient between the annual number of valuable patents of American machine toolmakers in Germany and German imports of machinery (1880-1913) comes to 0.45 , the correlation coefficient between the annual number of valuable patents of American machine toolmakers in Germany and German imports of machine tools $(1908-1932)$ to $0.18 .^{43}$ At least in the pre-First World War period, American firms might have increased their patent activities in Germany in response to growing business opportunities. $^{44}$

comparatively small and comes to 2 percent in the first imitation period, 3.4 percent in the first innovation period, 2.5 percent in the second imitation period, and 2.2 percent in the second innovation period.

${ }^{40} \mathrm{We}$ also compared the annual number of valuable patents of American machine toolmakers in Germany with American machine tool exports. The correlation coefficient between patents and exports comes to -0.46 .

${ }^{41}$ Statistisches Reichsamt (1881-1883), Statistik des Deutschen Reichs. Alte Folge, Statistisches Reichsamt (1884-1891, 1908), Statistik des Deutschen Reichs. Neue Folge, Statistisches Reichsamt (1892-1897, 1904, 1906, 1912, 1914), Vierteljahrshefte zur Statistik des Deutschen Reichs.

${ }^{42}$ Unfortunately, the German Statistical Office did not publish the value of imported machine tools before 1908. Statistisches Reichsamt (1900-1933), Monatliche Nachweise über den auswärtigen Handel Deutschlands. Berlin.

${ }^{43}$ The respective correlation coefficients between the patent activities of German firms and the two time series are 0.56 and 0 .

${ }^{44}$ After 1900 Germany was one of the most important foreign markets for American machine toolmakers who delivered about one-quarter of their total exports to German customers. See 


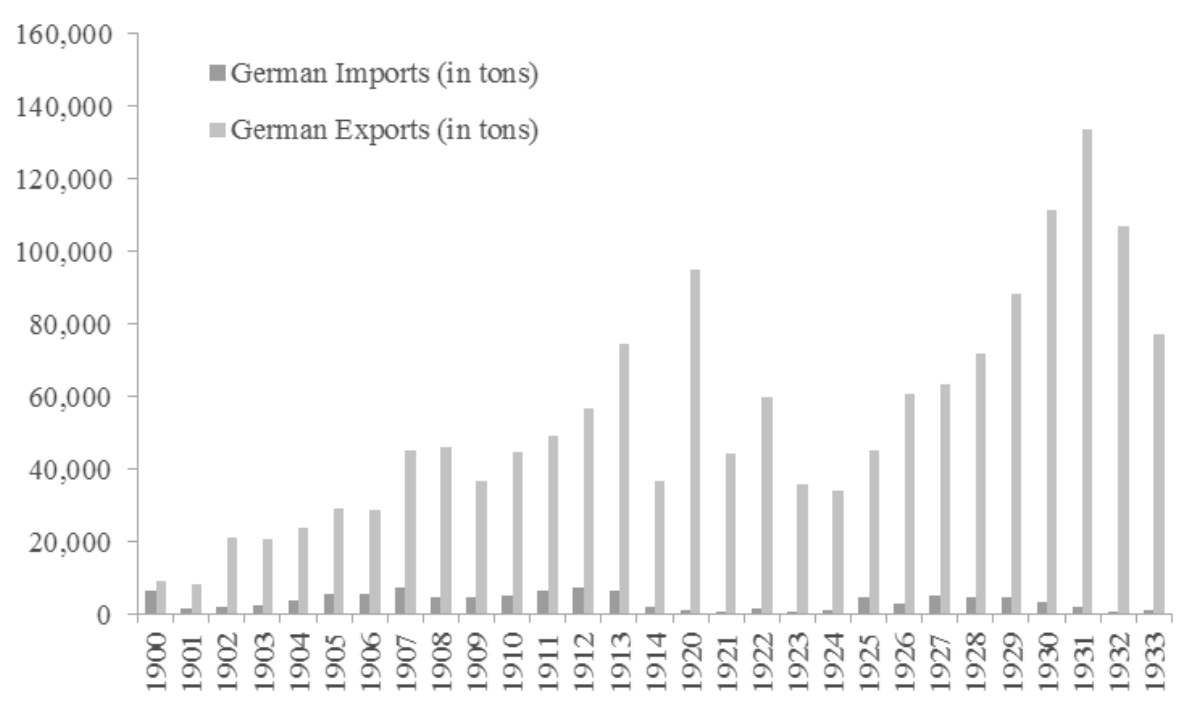

FIGURE 4

GERMAN EXPORTS AND IMPORTS OF MACHINE TOOLS IN TONS, 1900-1933

Source: Statitisches Reichsamt (1900-1933), Monatliche Nachweise.

Interestingly enough, it seems that three of the most notorious German imitators of the first imitation period, namely $J$. E. Reinecker, Pfauter, and Wanderer Works, ceased to market copies of new American machines (stopped their imitation strategies) after they transited to innovation. Indeed by then, these three firms also filed American patents for their new products. The best German firms now had a strong interest in seeing their own patents respected in their American export market, and thus they may have abstained from violating the intellectual property rights of American firms before the First World War. Figure 4 shows that German machine toolmakers increased their exports considerably during both innovation periods. This finding supports our contention that valuable patents are a reliable indicator for innovativeness and therefore also for international competitiveness. ${ }^{45}$

In the light of the increasing success of German firms in the American market, the German government was now also willing to make some concessions to the American patent holders. Section 11 of the 1891 German patent law ${ }^{46}$ preserved the 1877 rule that a patent could be revoked if the innovation was not manufactured

Robertson, "Changing Production,” p. 493; and Penrose and Williams, Duties, p. 236. William Brown claims "that innovations occurs when the demand for machine tools falls." See Brown, "Innovation." This hypothesis is not supported by our data.

${ }^{45}$ Labuske and Streb, "Technological Creativity."

${ }^{46}$ A similar ruling can be found in section 27 of the British Patents and Design Act of 1907. 


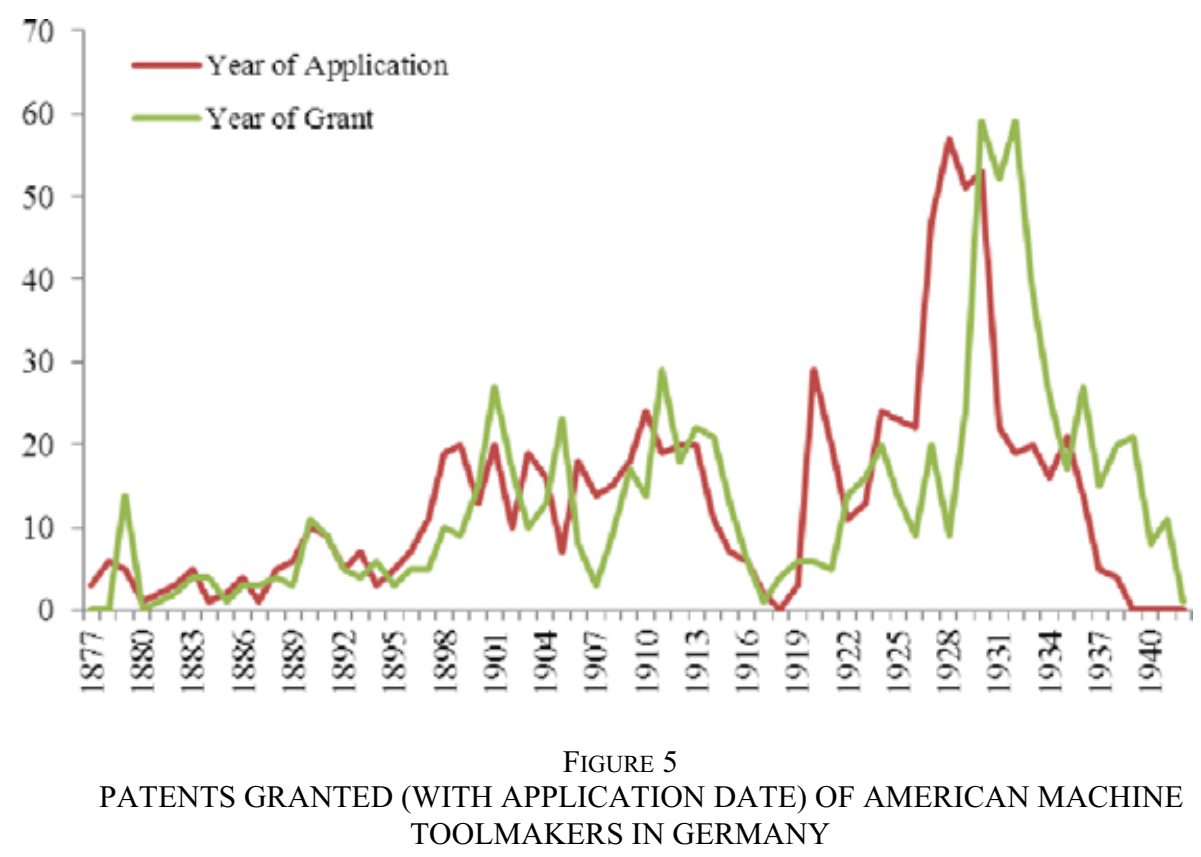

Source: Richter's patent data (available upon request).

in Germany. ${ }^{47}$ The purpose of this rule was to prevent a foreign patent holder from using his German patent to secure his monopoly without employing domestic labor or stimulating local industry. Since German firms used their American patents in the United States in exactly this way, in 1909 the German government agreed to exempt American firms from that section 11 of the German patent law. ${ }^{48}$

However, as we have already seen, in the early 1920s German firms reverted to copying foreign machines after losing their American patents during the war and falling technically behind. The Americans were well aware of the revitalized imitating activities of German firms in the 1920s. In 1925 American Trade Commissioner Theodor Pilger authored a report in which he listed 64 American machine toolmakers who had been squeezed out of the German and other export markets after their products had been copied by German firms. As Pilger had suggested, American firms applied for German patents to reduce such copying. ${ }^{49}$ Figure 5

\footnotetext{
${ }^{47}$ It was mainly the renowned and larger German machine builders that took licenses from the American patent holders.

48 "Abkommen zwischen dem Deutschen Reiche und den Vereinigten Staaten von Amerika, betreffend den gegenseitigen gewerblichen Rechtsschutz vom 23. Februar 1909." Blatt für Patent-, Muster- und Zeichenwesen, 25 August 1909, Nr. 7/8.

${ }^{49}$ See NARA, RG 151, 420 (Box 1950): W. H. Rastall to Julius Klein, 11 January 1926.
} 
TABLE 1

REVIEW PERIOD (TIME SPAN BETWEEN THE APPLICATION AND THE GRANTING) OF PATENTS OF MACHINE TOOLMAKERS FROM THE UNITED STATES AND CHEMNITZ, IN YEARS

\begin{tabular}{|c|c|c|c|}
\hline \multirow[t]{2}{*}{ Period } & \multicolumn{2}{|c|}{ Review Period } & \multirow[b]{2}{*}{$\begin{array}{l}\text { Disadvantage of the } \\
\text { American Applicant } \\
\text { (\%) }\end{array}$} \\
\hline & $\begin{array}{l}\text { Applicant from } \\
\text { Chemnitz }\end{array}$ & $\begin{array}{l}\text { American } \\
\text { Applicant }\end{array}$ & \\
\hline 1877-1899 & 0.7 years & 1.2 years & 64 \\
\hline 1900-1914 & 1.3 years & 2.2 years & 66 \\
\hline 1919-1925 & 1.7 years & 3.7 years & 116 \\
\hline $1926-1932$ & 2.3 years & 3.6 years & 51 \\
\hline
\end{tabular}

Source: Richter's patent data. A Chow test shows that, between 1919 and 1925, the disadvantage of American applicants with respect to the review period was significantly higher than in the rest of our observation period.

shows that American firms filed for an increasing number of patents in Germany after 1920, when German machine toolmakers' resumed imitating foreign products. However, because Berlin's patent office took about three and a half years to grant a patent to an American machine toolmaker, the number of patents granted increased only in the late 1920s, that is, in the second innovation period. In the decade that followed the First World War, American firms did in fact try to limit product piracy by increasing their German patenting activities but failed because of the patent office's dithering.

The German patent office's delay in granting patents in the 1920s might have reflected the growing complexity of the innovative machine tools. The patent authorities might also have chosen to delay grants to American firms to give domestic firms as much time as possible to exploit their imitation strategies. ${ }^{50}$ In effect, as Masaaki Kotabe has argued in another case, a country's patent practices discriminate against foreigners if the review period is systematically shorter for domestic applications than for foreign applications. ${ }^{51}$ Table 1 reveals that the German patent authorities took more time to evaluate American patent applications than those of Chemnitz (domestic) inventors. On average, this disadvantage comes to 60 percent. Between 1919 and 1925 however, the review period for American filers was more than twice of

\footnotetext{
${ }^{50}$ Before 1861 the American patent law also discriminated against foreigners. The statues of 1793, 1800, and 1832 restricted patent property to American citizens. In 1836 this stipulation was replaced with discriminatory patent fees demanded from foreign applicants. See Kahn, "Looking Backward," p. 333.

${ }^{51}$ Kotabe, "Comparative Study," p. 157. As a second indicator for discriminating patent practices, Kotabe suggests comparing the rejection rates of domestic and foreign patent applications. Unfortunately, we do not have information about the number of those machine toolmakers' patent applications that were rejected by the German patent office.
} 
domestic applicants. Then the difference in review time decreased again in the late 1920s and fell to an all-time low. In short, the quantitative evidence suggests that the patent office discriminated against foreign firms during the second imitation period.

There is also anecdotic evidence that American firms found it difficult to protect their intellectual property in the 1920s. Some American machine toolmakers needed more than ten years to fight their cases through the German patent court because several German companies joined to oppose their applications. ${ }^{52}$ The problems American manufacturers faced in dealing with the German patent office is illustrated by the experiences of Sol Einstein, head of the design engineering department of the Cincinnati Milling Machine Company: "It was difficult to get a German patent granted due to the opposition from German manufacturers. I therefore was sent to Germany to straighten out the difficulties our attorney experienced. When our opponents found out that I was in Germany to attend a hearing before the patent office, from month to month they postponed the hearings in the hope I would not stay in Germany. Finally after three months of delaying, the hearing was set. . . our opponents were willing to withdraw their position if we would grant them a license for using all twelve machines they had built. I insisted, however, on a ruling by the patent office which finally granted the patent with very broad claims." However, "through the united effort of a large number of German companies, the patent, after four years in existence, was declared invalid." ${ }^{, 3}$ It was the German Association of machine toolmakers which coordinated domestic firms' fight against the American patentees by collecting and encouraging patent appeals. ${ }^{54}$

Figure 5 shows that American firms' patent applications in Germany collapsed during the Great Depression. This decline continued in the Third Reich when business opportunities for American exporters of machine tools were restricted because National Socialists' foreign exchange controls reserved the use of scarce foreign currency mainly for the import of raw materials and food stuff. ${ }^{55}$

\footnotetext{
${ }^{52}$ CHSL, Milacron, Series: Misc. Folders (Schwartz), Box 1, Folder Litigation Compilation; Landesarchiv Berlin, Bestand Ludwig Loewe, A. Rep. 250/01/18/Karton 110 u. 130.

${ }^{53}$ CHSL, Milacron, Series: Executives Personal History (Schwartz), Box B-H, Folder Sol Einstein: Einstein, Sol, I do remember-men, machines, and the plants behind the Cincinatti Milling Machine Company, August 1972, p. 7.

${ }^{54}$ StA Chemnitz, Bestand Wanderer-Werke, 31030/WW3617: VDW to Wanderer-Werke, 23 January 1931.

${ }^{55}$ See, for example, Tooze, Wages, pp. 86-96.
} 


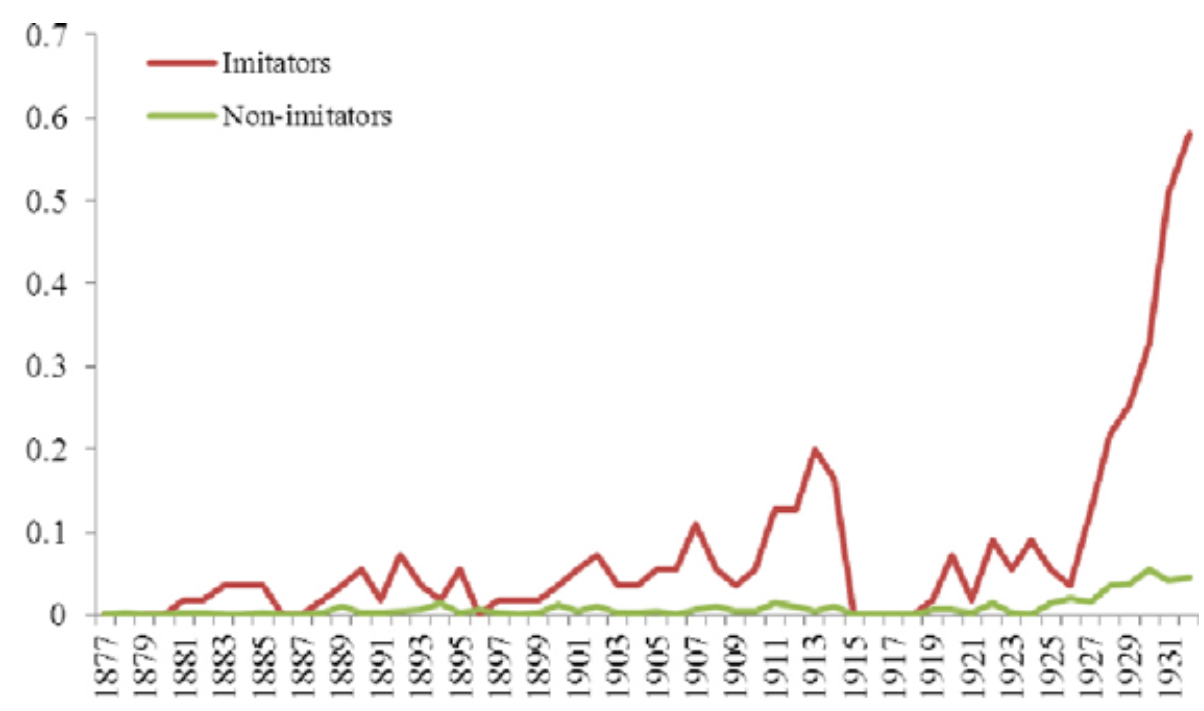

FIGURE 6

VALUABLE PATENTS PER IMITATING AND NON-IMITATING FIRM

Sources: Baten-Streb patent database and Richter's patent data (both available upon request).

Summing up, the degree of innovativeness of domestic firms significantly influenced the extent of the German patent office's discrimination against foreigners. In the decade before World War I when domestic firms were innovating, the patent authorities allowed American firms to hold patents for innovations not produced within the empire. In the second imitation period, the office forced American firms to face systematically longer review periods. It then changed course again in the second innovation period and brought differences in review times to an all-time low.

To prove our basic contention that learning by imitating fostered innovation we have to show that German imitators came to develop more novel machines than their non-imitator counterparts. To do so, we rely on the list of the 55 most notorious German imitators compiled by the Industrial Machinery Division of the American Department of Commerce and the National Machine Tool Builders Association. ${ }^{56} \mathrm{We}$ then calculate the annual number of valuable patents per firm for those on the American's list and for those firms who were members of the German machine tool builders association but did not make the list (see Figure 6). The notorious imitators were far more innovative

\footnotetext{
${ }^{56}$ See NARA, RG 151, 420 (Box 1950): D.P. Miller to Director Bureau of Foreign and Domestic Commerce, 8. November 1926.
} 
than the non-imitating firms, especially in the innovation periods. It thus seems that the ability to develop profitable innovations diffused first and foremost among imitating firms. Spending resources on imitation was apparently useful for secure firm's technical long-term technological growth.

Patenting activities in the German machine tool industry were not only unevenly distributed across firms but they were also clustered in a few administrative districts. Figure 7 shows the core areas of machine tool innovations in the $1890 \mathrm{~s}$ and the 1920s. The darker the shade, the higher the share of this district in all valuable machine tool patents. In the 1890s (1888-1897) machine toolmakers located in the three administrative districts of Saxony (Chemnitz, Dresden, and Leipzig) dominated patenting activities with a combined share of 46 percent in all valuable machine tool patents. In the 1920s (1918-1927), however, the geographical centers of patenting activities had shifted to Berlin (29 percent) and Magdeburg (12 percent) in the north, Duesseldorf in the west (17 percent) and Neckarkreis ( 9 percent) and Schwarzwald (8 percent) in the southwest. The combined share of the three administrative districts in Saxony had decreased to 15 percent though Saxony remained one of the major production centers of German machine tool industry.

One explanation for this change follows the hypothesis that the (local) availability of engineers and scientists with tertiary education is an important precondition for firms' capability to innovate. ${ }^{57}$ While it may not help us much with the original clustering, it can explain Saxony's relative decline in innovativeness because this region's universities did not participate in connecting science to research and development in the field of machine tool building before 1914. The first chair in machine tool building was established at Berlin's technical university in $1904 .^{58}$ The technical universities of Aachen, Braunschweig, Hannover, and Stuttgart also made such appointments before the First World War, whereas Dresden waited until 1923 to appoint a professor and open its first laboratory for machine tool building. ${ }^{59}$ Obviously, these provisions came too late to shift the geographical center of innovativeness back to Saxony.

\footnotetext{
${ }^{57}$ Mokyr, Lever, p. 244.

${ }^{58}$ Spur and Fischer, Georg Schlesinger, pp. 97-100.

${ }^{59}$ Hauptstaatsarchiv Dresden, 11125/15632; Ministerium für Kultus und öffentlichen Unterricht, Dresden an Rektor und Senat der Technischen Hochschule Dresden, 27 Februar 1923.
} 

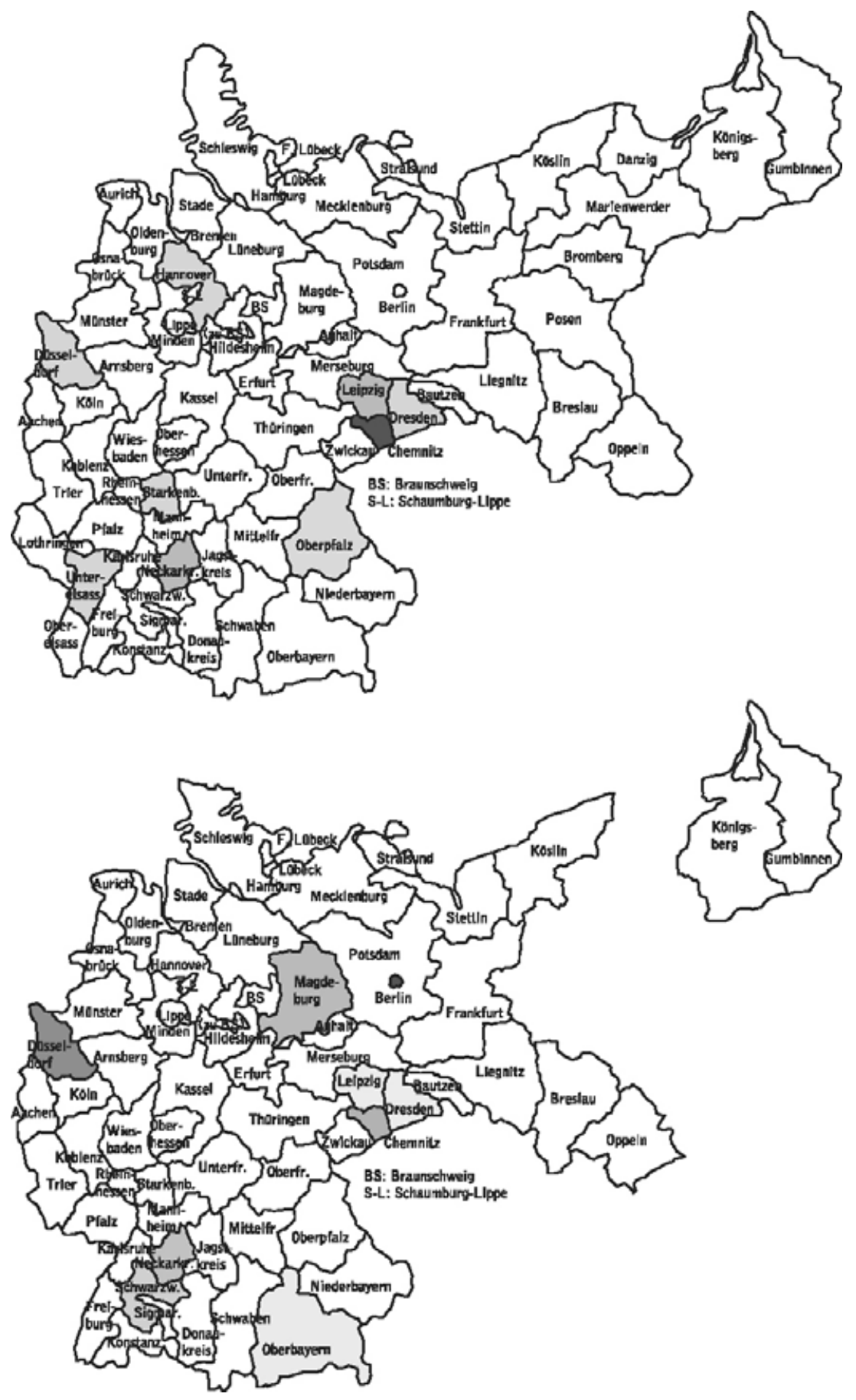

FIGURE 7

CORE AREAS OF PATENTING ACTIVITIES (VALUABLE PATENTS) IN THE GERMAN MACHINE TOOL INDUSTRY IN THE 1890S AND THE 1920S

Sources: Baten-Streb patent database and Richter's patent data (both available upon request). 


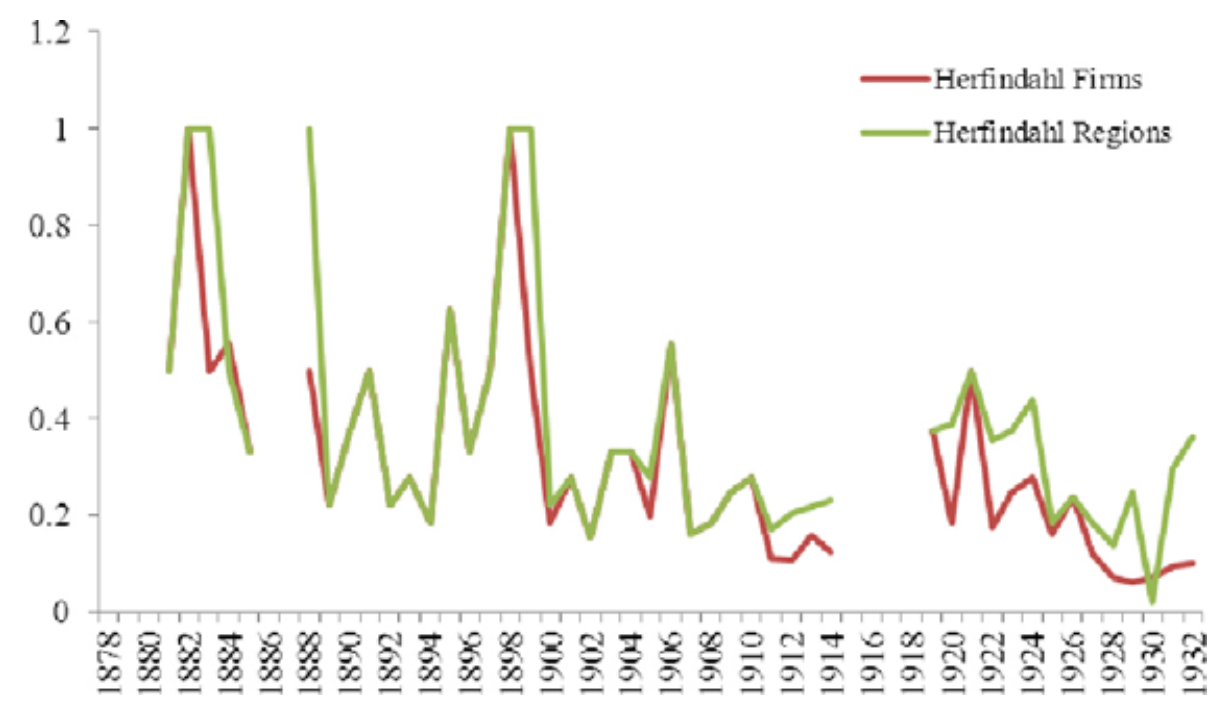

FIGURE 8

HERFINDAHL INDEX OF THE DISTRIBUTION OF VALUABLE PATENTS AMONG GERMAN MACHINE TOOLMAKERS

Sources: Baten-Streb patent database and Richter's patent data (both available upon request).

We claimed at the beginning of this article that innovation periods are often also times when knowledge diffuses to more and more domestic firms who can then develop and produce novel machine tools. To evaluate this hypothesis for our historical case we calculated, for every year, Herfindahl indices $(H)$ with respect to the distribution of valuable patents across both German firms and administrative districts. In the following formula, $t$ denotes the year, and $V P$ the number of valuable patents held either by firms $i=1 \ldots n$ or in administrative districts $i=1 \ldots n$ depending on whether the Herfindahl index is computed over firms or districts:

$$
H_{t}=\sum_{i=1}^{n}\left(\frac{V P_{i, t}}{V P_{t}}\right)^{2}
$$

The Herfindahl index equals one in the case of maximum concentration and to $1 / n$ in the case of an equal distribution of valuable patents, thus the smaller it is, the more equal is distribution of valuable patents. When the Herfindahl index decreases, innovation is becoming more diffuse. Figure 8 shows that both the firms' and the regions' Herfindahl indices are in fact decreasing during the two innovation periods (1900-1914 and 1926-1932), which implies that an increasing number of German machine toolmakers and German regions developed 
profitable innovations. Interestingly enough, the Herfindahl indices also fall at the beginning of the first imitation period which might reflect the general growth of the number of firms in the still young machine tool industry. During the intensification of the imitation period at the end of the nineteenth century, however, both Herfindahl indices increase-like in the second imitation period. This indicates the interruption of the former diffusion and might be explained by the fact that many of the German machine toolmakers lacked the resources to engage successfully in the learning by imitating process.

The firms' and regions' Herfindahl indices display a nearly time path because the above-average innovativeness of some regions is mostly based on the achievement of a small number of very innovative firms. ${ }^{60}$ Analyzing the patent activities in all German industries, Harald Degner finds that, the 30 most innovative German firms held a majority of all valuable patents (from 1877 to 1900, two-thirds, and, from 1901 to 1932, between 40 and 55 percent). ${ }^{61}$ We find this extraordinary skewness of the distribution of valuable patents also for the subgroup of machine tool builders. The five most innovative firms held 57 percent (1877-1899), 36 percent (1900-1914), 37 percent (1919-1925), and 42 percent (19261932) of all valuable patents granted to German machine tool builders in the respective periods. ${ }^{62}$

\section{CONCLUSIONS}

In 1880 German machine toolmakers lagged behind their American rivals, to catch up they relied on imitating and counterfeiting the better foreign machines. The same pattern was repeated after World War I set them back. The German administration supported this strategy by creating a patent law that discriminated against foreign patent holders and by prolonging the review period for foreign applicants. Imitation gave way to innovation both at the very end of the nineteenth century and at the very end of the 1920s. Each time as German firms became technically more competitive internationally, the willingness to

\footnotetext{
${ }^{60}$ Note that the diverging development of both Herfindahl Indices in the early 1930s resulted from the fact that an increasing number of firms located in Berlin held an increasing number of valuable patents.

${ }^{61}$ Degner, "Schumpeterian German Firms," p. 62. See also "Booms."

${ }^{62}$ The five most innovative firms were J. E. Reinecker, Pittler Werkzeugmaschinenfabrik, Maschinenfabrik Lorenz AG, Wohlenberg, H. KG Drehbankfabrik und Eisengießerei and Dresdner Bohrmaschinenfabrik between 1877 and 1899, Mayer \& Schmidt Schleifmaschinen- und Schmirgelwerke, Schultz, Friedrich GmbH, Fortuna-Werke Spezialmaschinenfabrik, Fritz Werner and J. E. Reinecker between 1900 and 1914, A. Monforts Maschinenfabrik, RabomaMaschinenfabrik Hermann Schoening, Ludw. Loewe \& Co AG, Fritz Werner and Lindner, Herbert Erste Spezialfabrik für Teilapparate between 1919 and 1925, and Fritz Werner, Lindner, Herbert Erste Spezialfabrik für Teilapparate, Carl Hasse \& Wrede GmbH, Index-Werke Hahn \& Kolb and Schiess-Defries-AG between 1926 and 1932.
} 
guarantee foreign intellectual property rights increased. A key reason for this policy change came from German firms who now had to fear retaliatory measures in their export markets when violating foreign property rights within Germany.

The development of the German machine tool industry has many historical and contemporary echoes. ${ }^{63}$ Developing countries may learn from these examples that the strict compliance to the international rules of law with respect to intellectual property rights can slow down the speed of technological and economic progress in their domestic industry. ${ }^{64}$ Advanced countries may understand, first, that they owe their own development to similar imitating strategies in the past, and, second, that there is a good chance that illegal imitation only takes place during a transitional period. It is true that not in every technologically backward country a period of imitation will inevitably lead to a period of innovation. Still, many historical cases support the view that learning by imitation is a very promising way to catch up to advanced foreign industries. It is therefore conceivable that the copying and counterfeiting activities of the Chinese machine builders which have been long tolerated by their government will end as soon as these firms find significant foreign markets for advanced and innovative machinery.

\footnotetext{
${ }^{63}$ Other cases are, for example, the imitation of British agricultural machinery and synthetic dye technology by German firms and the imitation of German Diesel engines by American firms. See Herrmann, Pflügen, pp. 179-81; Murmann, Knowledge; and Braun, "Technologietransfer."

${ }^{64}$ See the similar conclusion in Boldrin and Levine, Against Intellectual Monopoly, p. 281.
}

\section{REFERENCES}

Abramovitz, Moses. "Catching-Up, Forging Ahead, and Falling Behind." The Journal of Economic History 46, no. 2 (1986): 385-406.

Aghion, Phillipe. "Higher Education and Innovation." Perspektiven der Wirtschaftspolitik 9 (Special edition 2008): 28-45.

American Machinist, various years.

Argumentationshilfe aus dem VDMA zum Stichwort Produktpiraterie, Press release VDMA, March 2008.

Boldrin, Michele, and David K. Levine. Against Intellectual Monopoly. Cambridge: Cambridge University Press, 2008.

Braun, Hans-Joachim. "Technologietransfer im Maschinenbau von Deutschland in die USA,1870-1939." Technikgeschichte 50, 2 (1983): 238-52.

Brown, William H. "Innovation in the Machine Tool Industry." Quarterly Journal of Economics 71, no. 4 (1957): 406-25.

Buchheim, Christoph. "What Causes Late Development? Insights from History." South African Journal of Economic History 21, no. 1 (2006): 52-83. 
Bundesarchiv Berlin-Lichterfelde, Stenographischer Bericht über die Besprechung in den Geschäftsräumen des Vereins Deutscher Werkzeugmaschinenfabriken, 5 September 1916, R 8099/259, 26-32.

Burhop, Carsten. "The Transfer of Patents in Imperial Germany." The Journal of Economic History 70, no. 4 (2010): 921-39.

Cincinnati Historical Society Library, Milacron, Series Frederick V. Geier, Box 53: Amortization of Machine Tools, May 1930.

. Milacron, Series: Misc. Folders (Schwartz), Box 1, Folder Litigation Compilation.

Milacron, Series: Executives Personal History (Schwartz), Box B-H, Folder Sol Einstein: Einstein, Sol, I do remember-men, machines, and the plants behind the Cincinatti Milling Machine Company, August 1972.

Degner, Harald. "Schumpeterian German Firms Before and After World War I: The Innovative Few and the Non-Innovative Many." Zeitschrift für Unternehmensgeschichte 54, 1 (2009): 50-72.

"Do Technological Booms Matter? New Evidence on the Relationship Between Firm Size and Innovativeness." Cliometrica 5, 2 (2011): 121-44.

Degner, Harald, and Jochen Streb. "Foreign Patenting in Germany, 1877-1932." FZID Discussion Papers 21, Hohenheim 2010.

Gebr. Heinemann AG, 1877-1937. St. Georgen im Schwarzwald: 1937.

Goodfriend, Marvin, and John McDermott. "Industrial Development and the Convergence Question.” American Economic Review 88, no. 5 (1998): 1277-89.

Grupp, Hariolf, Icias Dominguez-Lacasa, and Monika Friedrich-Nishio. Das deutsche Innovationssystem seit der Reichsgründung. Heidelberg: Physica Verlag, 2002.

Hauptstaatsarchiv Dresden, 11125/15632; Ministerium für Kultus und öffentlichen Unterricht, Dresden an Rektor und Senat der Technischen Hochschule Dresden, 27 Februar 1923.

Herrmann, Klaus. Pflügen, Säen, Ernten. Reinbek bei Hamburg: Rowohlt, 1985.

Jeremy, David J., ed. International Technology Transfer: Europe, Japan, and the USA, 1700-1914. Aldershot: Edward Elgar, 1991.

Kahn, Zorina. "Looking Backward: Founding Choices in Innovation and Intellectual Property Protection." In Founding Choices: American Economic Policy in the 1790s, edited by Douglas Irwin and Richard Sylla, 315-42. Chicago: University of Chicago Press, 2011.

Kelly, Morgan. "Technological Progress Under Learning by Imitating." International Economic Review 50, no. 2 (2009): 397-414.

Kiesewetter, Hubert. "Beasts or Beagles? Amerikanische Unternehmen in Deutschland." In Der Einfluß ausländischer Unternehmen auf die deutsche Wirtschaft vom Spätmittelalter bis zur Gegenwart, edited by Hans Pohl, 165-96. Stuttgart: Franz Steiner, 1992.

Kotabe, Masaaki. "A Comparative Study of U.S. and Japanese Patent Systems." Journal of International Business Studies 23, no. 1 (1992): 147-68.

Labuske, Kirsten, and Jochen Streb. "Technological Creativity and Cheap Labour? Explaining the Growing International Competitiveness of German Mechanical Engineering Before World War I." German Economic Review 9, no. 1 (2008): 65-86.

Landes, David S. The Unbound Prometheus: Technological Change and Industrial Development in Western Europe from 1750 to the Present. 2nd edition. Cambridge: Cambridge University Press, 2003.

Landesarchiv Berlin, Bestand Ludwig Loewe, A. Rep. 250/01/18/Karton 110 u. 130. 
Miller, Fred J. American and Other Machinery Abroad: Being a Study of the European Field for the Introduction of American Machinery. New York: Press of the American Machinist, 1897.

."German Tool Shop." American Machinist (November 1898): 818.

Mokyr, Joel. The Lever of Riches: Technological Creativity and Economic Progress. Oxford: Oxford University Press, 1990.

Moser, Petra. "How Do Patent Laws Influence Innovation? Evidence from NineteenthCentury World's Fairs." American Economic Review 95, no. 4 (2005): I214-36.

Murmann, Johann Peter. Knowledge and Competitive Advantage: The Coevolution of Firms, Technology, and National Institutions. Cambridge: Cambridge University Press, 2003.

Penrose, B., and J. S. Williams. Duties on Metals and Manufacturers of Metals. Committe on Finance, United States Senate. Washington, DC: GPO, 1912.

Produkt- und Markenpiraterie in der Investitionsgüterindustrie 2008, Press release VDMA, April 2008.

J. E. Reinecker Chemnitz, 1859-1909. Leipzig: Meisenbach Riffarth, 1909.

Richter, Ralf. "Der amerikanische und deutsche Werkzeugmaschinenbau zwischen Konvergenz und Divergenz, 1870-1933." Ph.D. Diss., Bielefeld, 2012.

Robertson, Robert M. "Changing Production of Metalworking Machinery, 1860-1920." In Output, Employment, and Productivity in the United States After 1800, edited by D. S. Barry, 479-96. New York: Columbia University Press, 1966.

Seckelmann, Margrit. Industrialisierung, Internationalisierung und Patentrecht im Deutschen Reich, 1871-1914. Frankfurt/Main: Vittorio Klostermann, 2006.

Spur, Günter, and Wolfram Fischer, ed. Georg Schlesinger und die Wissenschaft vom Fabrikbetrieb. Munich: Hanser Verlag, 2002.

Staatsarchiv Chemnitz, Schätzungsprotokolle über Betriebsgegenstände, 1915, $31007 / 131$.

Bestand Wanderer-Werke, VDW to Wanderer-Werke, 23 January 1931, 31030/WW3617.

Statistisches Reichsamt. Monatliche Nachweise über den auswärtigen Handel Deutschlands. Berlin: Puttkammer \& Mühlbrecht, 1900-1933.

. Statistik des Deutschen Reichs. Alte Folge, Berlin: Puttkammer \& Mühlbrecht, 1881-1883.

. Statistik des Deutschen Reichs. Neue Folge. Berlin: Puttkammer \& Mühlbrecht, 1884-1891, 1908.

. Vierteljahrshefte zur Statistik des Deutschen Reichs, Berlin: Puttkammer \& Mühlbrecht, 1892-1897, 1904, 1906, 1912, 1914.

Streb, Jochen. "Möglichkeiten und Grenzen der Schumpeterschen Diversifizierung. Die Entwicklung der Firma Freudenberg \& Co. Weinheim vom spezialisierten Ledererzeuger zum Kunststoffverarbeiter mit breiter Angebotspalette." Zeitschrift für Unternehmensgeschichte 46, no. 2 (2001): 131-59.

Streb, Jochen, Jörg Baten, and Shuxi Yin. "Technological and Geographical Knowledge Spillover in the German Empire, 1877-1918." Economic History Review 59, no. 2 (2006): 347-73.

Thurston, Robert Henry. Report on Machines and Manufacturers: With an Account of European Manufacturing Districts; Vienna International Exhibition 1873. Washington, DC: GPO, 1875.

Tooze, Adam. The Wages of Destruction: The Making and Breaking of the Nazi Economy. London: Penguin, 2006. 
U.S. National Archives and Records Administration, W. H. Rastall to Julius Klein, 11 January 1926, RG 151, 420 (Box 1950).

D. P. Miller to the Director Bureau of Foreign and Domestic Commerce, 8 November 1926, RG 151, 420 (Box 1950).

. W. H. Rastall, 2 May 1927, RG 151, 413 (Box 1806). 